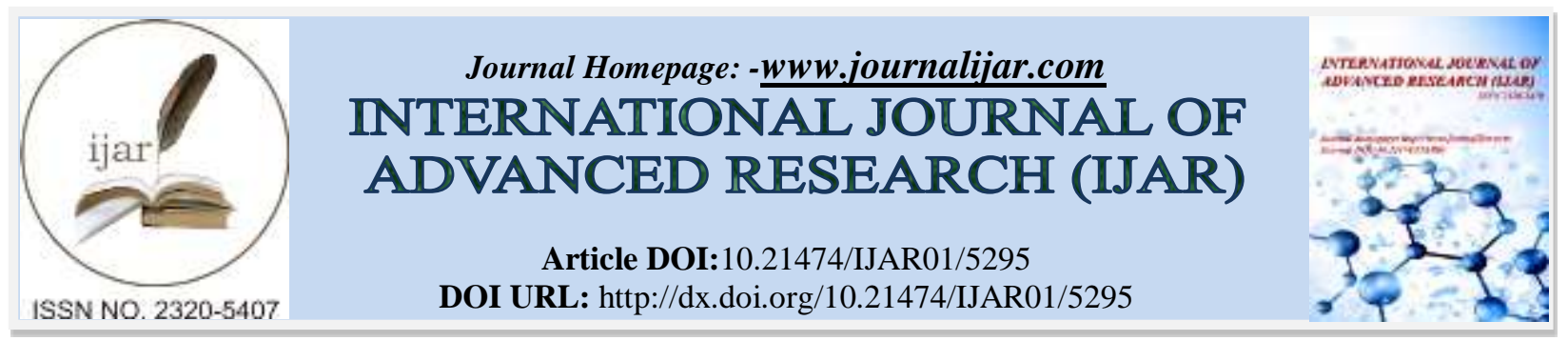

RESEARCH ARTICLE

\title{
HYPOGLYCAEMIC AND HYPOLIPIDEMIC EFFECTS OF POLYHERBAL FORMULATION IN STREPTOZOTOCIN-INDUCED DIABETIC RATS.
}

\section{Aliu Hamel Oyindamola ${ }^{1}$, Anyasor Godswill Nduka ${ }^{2}$, Adaramola Feyisara Banji ${ }^{1}$, Aleshinloye Abimbola Ololade $^{1}$ and Onigbinde Adebayo Omotayo ${ }^{1}$.}

1. Department of Basic Sciences, Chemistry Unit, Babcock University, Ilishan-Remo, Ogun State, Nigeria. P.M.B. 21244 Ikeja Lagos Nigeria.

2. Department of Biochemistry, Benjamin S. Carson (Snr.) School of Medicine, Babcock University, Ilishan-

Remo, Ogun State, Nigeria. P.M.B. 21244 Ikeja Lagos Nigeria.

\section{Manuscript Info}

Manuscript History

Received: 01 July 2017

Final Accepted: 03 August 2017

Published: September 2017

Keywords:-

Diabetes, Lipid profile, Polyherbal formula, Hypolipidemia, Streptozotocin, hyperglycaemia.

\section{Abstract}

This study evaluated the effects of a polyherbal formula on the plasma lipid profile and blood glucose in Streptozotocin-induced diabetic rats. A single dose of Streptozotocin (STZ), $(60 \mathrm{mg} / \mathrm{kg}$ body weight) in sodium citrate buffer at $\mathrm{pH} 4.5$ was used to induce diabetes intraperitoneally in 20 adult Albino Wistar Strain Rats. 25 rats were put into 5 groups: Normal, Standard, Control, Test I and Test II respectively and were sacrificed after 7days of treatment. The weight and glucose baseline were taken prior to: (1) STZ administration (2) after a week of inducing diabetes (3) after the first, third and fifth day of treatment and (4) at sacrificial time. The body weight and blood glucose level of all animals in different groups varied depending on treatment. Blood glucose test showed that there was a significant increase in blood glucose level after induction. After treatment, the normal group blood glucose level increased by $19.12 \%$ but not diabetic, and a decrease of $10.61 \%, 61.64 \%, 48.19 \%$ and $77.16 \%$ for the Control, Standard, Test I and Test II respectively. The body weight for normal group increased by $6.29 \%$ while the Control group, Standard group, Test I and Test II emaciated by $7.91 \%, 3.35 \%, 6.9 \%$ and $5.1 \%$ respectively. The lipid profile test showed that Test I and Test II groups have lower lipid values compare with other study groups. Results from this study clearly indicated that the polyherbal formula had hypoglycaemic and hypolipidemic effects on Streptozotocin-induced diabetic rats.

Copy Right, IJAR, 2017,. All rights reserved.

\section{Introduction:-}

Diabetes mellitus, often referred to as diabetes is a choric disease and one of the most common diseases in our world today, which has increased the mortality rate drastically. In times past, only aged men and women were diagnosed of diabetes, but now, both old and young are susceptible to diabetes. Diabetes mellitus is often called 'The silent killer', because it causes serious complications without serious symptoms and can affect many of major organs in the body (Papaspyros, 1964). Many authors have tried to define diabetes, but, going by the definition of the World Health Organization (WHO) on the basis of laboratory findings, diabetes mellitus is characterized by a fasting 
venous plasma glucose concentration greater than $7.8 \mathrm{mmol} / \mathrm{l}(140 \mathrm{mg} / \mathrm{dl})$ or greater than $11.1 \mathrm{mmol} / \mathrm{l}(200 \mathrm{mg} / \mathrm{dl})$ two hours after a carbohydrate meal or two hours after an oral ingestion of the equivalent of $75 \mathrm{~g}$ glucose, even if the fasting concentration is normal (Nwanjo and Nwokoro, 2004). A study conducted by the World Health Organization reported that the worldwide prevalence of diabetes in 2002 was 170 million, with the number predicted to grow to 366 million by 2030 (Wild et al., 2004).

The Diabetes Association (ADA, 1998) says that chronic hyperglycaemia is associated with microvascular and macrovascular complication that can lead to visual impairment, blindness, kidney disease, nerve damage, amputations, hyperlipidaemia, heart disease, and stroke. This implies that diabetic individuals are at the risk of developing series of other health problems apart from hyperglycaemia .There are two major types of diabetes: type I and type II diabetes (National Diabetes Fact Sheet, 2011).

There is an increased focus on plants in the search for appropriate hypoglycaemic and anti-hyperglycaemic agents for diabetic conditions (Ebong et al., 2008). Not all plants prepared and administered locally have been tested and proven scientifically to justify their traditional uses and potencies. Diabetes can only be managed throughout an individual's life time (Londhe, et al., 2011; Uma et al., 2014).

The Wistar rat is an outbred albino rat that is used to mimic diabetes in humans. The most commonly used drug for this induction is Streptozotocin (STZ) because of its toxic effects on islet beta cells (Fadillioglu et al., 2008). (Rakieten et al., 1963; Ar'Rajab and Ahrén 1993; Gu et al., 1997). Co-morbid diseases with hyperglycaemia include high cholesterol, loss of body weight, loss of appetite etc. The plasma lipid profile consists of the total cholesterol, high density lipoproteins (HDL), the triglycerides and the low density lipoproteins (LDL).

Garlic, Allium sativum, is a member of the Alliaceae family, has been widely recognized as a valuable spice and a popular remedy for various ailments and physiological disorders. The active constituents are sulfur-containing compounds that are rapidly absorbed and metabolized. Numerous studies on garlic have suggested that garlic lowers total cholesterol concentrations favorably altering HDL/LDL ratios (Singh and Singh, 2008, Bordia (1981).

Garlic contains at least 33 sulfur compounds, several enzymes and the minerals vitamins, fiber amino acids and water (Josling, 2005; Fenwick and Hanley, 1985).

Ginger, Zingiber officinale, is one of the most widely consumed tuberous spices worldwide. In time past it has been of use as herbal medicine for the treatment of a variety of ailments, including vomiting, pain, indigestion, and coldinduced syndromes, tumor (Wang and Wang, 2005; Shailah, 2010; Khadem et al., 2008). Ginger exists in quite a number of varieties. Nigerian ginger is darker in colour, minute size, and has a more pungent taste (Duke and Ayensu, 1985).

The major active ingredients in ginger oil are sesquiterpene, bisapolene, zingiberene, and zingiberol, glycolipids and oleoresin (Connell and Sutherland, 1969, Newall et al., 1996, Chrubasik et al., 2005). According to Firas (2013), polyherbal mixture has synergistic effect on regulating blood glucose than individual plants.

Bitter melon, Mormodica charantia, is a tropical and subtropical vine of the family Cucurbitaceae, widely grown in Asia, Africa and the Caribbean for its edible fruit. The fruit is among the most bitter of all fruits and is one of the well-known medicinal plants (Alamgir et al., 2012).

All parts of the plant taste bitter and it contains biologically active chemicals include glycosides, saponins, alkaloids, fixed oils, triterpenes, proteins and steroids ((Alamgir et al., 2012, Raman and Lau, 1996). It is used in traditional medicine to treat stomach pain, diabetes, fevers, colds, coughs, headaches, malaria, skin complaints, menstrual disorders, aches and pains, hypertension, infections, and as an aid in childbirth (Leslie, 2002).

Onion, Allium cepa, is one of the most important commercial condiment vegetable grown and consumed all over the world. Onions are perennials, where the fleshy bulb that grows below the ground is used medicinally as well as for food (Farooqui and Kumar, 2003).

The volatile oils and allyl propyl sulphide present in onion is responsible for the appealing flavour. There are three types of colour onions: white, yellow and red. Cutting onions causes irritation to the eyes due to the presence of a 
phytonutrient called IsoAlliin.. Onion has been experimentally documented to possess anti-diabetic potential anti hyperlipidaemia and bone inhibitory effect (Muhlbauer et al., 2002).

Grape fruit, Citrus paradise, belongs to the Citrus genus, in the family Rutaceae (Uysal et al., 2011). Citrus contain a high amount of useful by-products which include essential oil. It is consumed fresh or used as raw materials for juice and wine (Schieber et al., 2001). Grape is one of the citrus fruits cultivated and consumed in Nigeria (Odubanjo and Sangodoyin, 2002). They have been used medically for liver cleansing, boosting the immune system, treating respiration issues and to reduce hearth disease risk.

In this research, the effects of polyherbal mixture on blood glucose and the plasma lipid profile level of Streptozotocin-induced diabetic rats was investigated.

\section{Materials and Methods:-}

The experiment was carried out in the Chemistry laboratory, Biochemistry laboratory and the Animal house at Babcock University, Ilishan-Remo, Ogun state. Nigeria.

\section{Plant materials, Drugs and Chemicals:-}

Selected plants; ginger, garlic, onion, grape fruit, and bitter melon were obtained from a local market at Ikorodu, Lagos State, Nigeria. The standard drug glybenclamide (Daolin, Aventis Pharma, U.K.) and Accu-Chek glucometer (Accu-Chek, USA) and the lipid profile diagnostic kits (QCA Spain cholesterol Kit and SPINREACT triglycerides kit, Spain) were purchased from a Pharmacy in Lagos State Nigeria. Streptozotocin (Sigma, USA), Lithium Heparin bottles (BD, USA), plastic syringes were purchased from a chemical supplier in Lagos Nigeria.

\section{Animals:-}

Thirty male albino rats (Wistar strain) weighing between $150-200 \mathrm{~g}$ and their cages were purchased from an inbred colony, in the Animal Facility Unit, Babcock University, Ogun state, Nigeria. Animals were allowed to acclimatize for two weeks before commencement of study and were given commercial rat chow and water ad libitum. Animal experimental protocols were in conformity with the National Institute of Health/National Research Council Regulations on Laboratory Animal Care and Use Guidelines (NIH, 2010). Ethical clearance was obtained from Babcock University Health Research Ethical Committee (BUHREC699/16, January 2017). Glibenclamide was used as the standard drug for treating diabetes. The glucometer kit was bought at a pharmacy in Lagos state. EDTA bottles, Syringes and the lipid profile test kits were bought from a supplier in Ogun state.

\section{Preparation of Polyherbal formula:-}

The selected plants were gotten from a local market in Ikorodu, Lagos State Nigeria and were identified by a Professor of Botany in the Basic sciences Department of Babcock University. Bitter melon leaves, ginger, garlic, onion and grape were separately washed thoroughly with water in order to remove dirt and allowed to air dry. After $24 \mathrm{~h}$, the mesocarp of each plant materials was completely peeled off, sliced into smaller parts to aid drying and placed in the oven at a temperature of $60^{\circ} \mathrm{C}$ for $24 \mathrm{~h}$. Dried plant materials $(100 \mathrm{~g})$ were then pulverized using laboratory blender and soaked in warm water for $24 \mathrm{~h}$. Subsequently, the suspension was then filtered using Whatman No.1 filter paper and the suspension was subsequently concentrated using a rotary evaporator (Eyela N1001) at $40^{\circ} \mathrm{C}$. The concentrate was stored in the refrigerator at $4^{\circ} \mathrm{C}$ until further use.

\section{Induction of diabetes:-}

Rats were fasted for $16 \mathrm{~h}$ before the induction of diabetes with Streptozotocin (STZ) (Sigma, USA). A freshly prepared solution of $60 \mathrm{mg} / \mathrm{kg} \mathrm{STZ}$ in $0.1 \mathrm{M}$ cold citrate buffer, $\mathrm{pH}: 4.5$, was injected intraperitoneally and the normal rats were injected with citrate buffer alone in accordance with the method described by Zafar et al (2009). In order to control the hypoglycaemia during the first day after the STZ administration, diabetic rat were given $5 \%$ glucose solution orally. Hyperglycaemia was confirmed by the elevated fasting glucose level in the blood at $48 \mathrm{~h}$ and on day 6 after injection. Rats with diabetes exhibiting fasting blood glucose levels $>240 \mathrm{mg} / \mathrm{dL}$ were selected for the study.

\section{Treatment of diabetic rats:-}

A week after the STZ induction, the diabetic rats were selected and put in four (4) groups of five (5) each. The control group was not given any treatment. The standard group was administered with $2.5 \mathrm{mg} / \mathrm{kg}$ body weight 
(B.W.) Glybenclamide. Test I and test II groups were administered with $50 \mathrm{mg} / \mathrm{kg}$ and $100 \mathrm{mg} / \mathrm{kg}$ body weight polyherbal formula respectively. The treatment period lasted for 7 days.

\section{Collection of blood samples for plasma preparation:-}

Blood samples were collected from the petroleum ether anesthetized rats by cardiac puncture using $5 \mathrm{ml}$ hypothermal syringe and transferred into lithium heparin bottles. The blood was centrifuged at $3000 \mathrm{rpm}$ for $10 \mathrm{~min}$ using a table top centrifuge. The clear supernatant (plasma) was used for the lipid profile assay in accordance with the method described by the QCA Spain cholesterol kits and SPINREACT Spain triglycerides kit. For the blood glucose assessment, each rat was held carefully while the tail tip was gently cut to collect few drops of blood. The glucometer strip was inserted into the glucometer (Accu-Chek Active) and the blood sample was dropped on the brown portion of the strip after 5 seconds of inserting the strip. The concentration of blood glucose was measured from the digital reading.

\section{Result and Discussion:-}

In this study, the effect of polyherbal formula extracts on Streptozotocin-induced diabetic rats was investigated. The plasma lipid profile and blood glucose in the diabetic rats were measured. Streptozotocin (STZ) $(60 \mathrm{mg} / \mathrm{kg}$ body weight (BW)) was injected once intraperitoneally to induce diabetic condition by signs and symptoms of diabetes ((Piyachaturawat et al 1991).

Table 1 shows how the rats were grouped and treated. Tables 2 and 3 and figure 1 show the average body weights of the rats before induction, after a week of induction and after a week of treatment with the polyherbal formula. The body weights of the normal group increased by $\sim 2.9 \%$ while control, standard, Test I, and Test II groups decreased by $\sim 2.1,2.1,2.0$ and $2.4 \%$ respectively. The increase in the normal group body weight is an indicator of total wellbeing and good feeding. The decrease in body weight of other groups is a clinical symptom of the diabetic condition of the rats as a result of appetite loss and polyuria (White and Baxter, 1994). Figure 2 and data in Table 3 show that 50 and $100 \mathrm{mg} / \mathrm{kg}$ polyherbal formula and standard drug treated diabetic rats had significantly reduced $(\mathrm{P}<0.05)$ blood glucose concentrations when compared with untreated diabetic rats from day 3 to 7 post-induction of diabetes. In addition, the blood glucose level of the $100 \mathrm{mg} / \mathrm{kg}$ body weight (BW) polyherbal formula treated animals were significantly $(\mathrm{P}<0.05)$ reduced when compared with standard drug treated animals from day 3 to 7 post-induction of diabetes. This indicates that polyherbal formula possesses the capacity to reduce blood glucose level in diabetic condition. Previous studies (www.ncbi.nlm.nih.gov, 2007; www.diabetes.co.uk) have shown that an herbal mixture that reduces blood glucose level possesses antidiabetic property. Glybenclamide elicits its antidiabetic effect by stimulating secretion of insulin. This also suggests that polyherbal formula may have reduced blood glucose level through stimulation of insulin secretion.

Evaluation of the effects of polyherbal formula on lipid profile of diabetic animals is shown in Tables 5, 6, and 7. The tables show that 50 and $100 \mathrm{mg} / \mathrm{kg}$ polyherbal formula treated diabetic rats had significantly reduced $(\mathrm{P}<0.05)$ LDL-cholesterol, total-cholesterol and triglycerides when compared with untreated diabetic rats in a dose dependent manner. This observation was comparable to standard drug treated group. Data indicated that polyherbal formula possesses hypocholesterolaemic property in diabetic condition. More so, 50 and $100 \mathrm{mg} / \mathrm{kg}$ polyherbal formula and standard drug treated diabetic rats had significantly elevated $(\mathrm{P}<0.05)$ HDL-cholesterol level when compared with untreated diabetic rats. From the results, it appeared that the efficacy of the plant extracts declined with time. So, it is suggested that its storage time should not be more than five (5) days. This justifies the use of these plants in traditional medicine for the management of high blood pressure and hyperglycaemia.

\section{Conclusion:-}

The result showed that the polyherbal formula was effective for the treatment of diabetes and for regulating the lipid profile. It is recommend that further research should be carried out on the polyherbal formula to ascertain its chemical composition and fully elucidate its antidiabetic mechanism of action.

Table 1:- Diabetic groups and detailed protocol and treatment.

\begin{tabular}{|l|l|}
\hline Groups & Treatment protocol \\
\hline Normal & Normal, neither STZ-induced nor treated. \\
\hline Standard & STZ-induced diabetes and treatment with Glybenclamide (standard) \\
\hline
\end{tabular}




\begin{tabular}{|l|l|}
\hline Control & STZ-induced diabetes without any treatment \\
\hline Test I & STZ-induced diabetes and treatment with $50 \mathrm{mg}$ plant extracts \\
\hline Test II & STZ-induced diabetes and treatment with $100 \mathrm{mg}$ plant extracts \\
\hline
\end{tabular}

Table 2:-Average body weights of rat groups before induction, after induction and after treatment.

\begin{tabular}{|l|l|l|r|r|}
\hline Group & $\begin{array}{l}\text { Body Weight(g) } \\
\text { Before }\end{array}$ & $\begin{array}{l}\text { Body Weight(g) After 7 Days of } \\
\text { Induction }\end{array}$ & $\begin{array}{l}\text { Body Weight(g) } \\
\text { Treatment }\end{array}$ & After 7 Days of \\
\hline Normal & $170 \pm 0.051$ & $175 \pm 0.2$ & & $186 \pm 0.32$ \\
\hline Control & $142 \pm 0.045$ & $139 \pm 0.45$ & & $128 \pm 0 . .45$ \\
\hline Standard & $183 \pm 0.018$ & $179 \pm 0.08$ & & $173 \pm 0.32$ \\
\hline Test I & $148 \pm 0.125$ & $145 \pm 0.125$ & & $134 \pm 0.5$ \\
\hline Test II & $161 \pm 0.102$ & $157 \pm 0.2$ & $149 \pm 0.23$ \\
\hline
\end{tabular}

Data are averages of two determinations

Table 3:-Post Induction Treatments of Diabetic Rat.

\begin{tabular}{|c|c|c|c|c|c|}
\hline Group & $\begin{array}{l}\text { After a week of Inducing } \\
\text { Diabetes }\end{array}$ & $\begin{array}{l}\text { Treatment } 0 \\
\text { Diabetes }\end{array}$ & & & \\
\hline & & Day 1 & Day 3 & Day5 & Day 7 \\
\hline Normal & $68 \pm 0.625$ (not induced) & $60 \pm 0.03$ & $59 \pm 0.03$ & $74 \pm 0.03$ & $81 \pm 0.26$ \\
\hline Control & $490 \pm 0.745$ & $494 \pm 0.05$ & $491 \pm 0.05$ & $475 \pm 0.05$ & $438 \pm 1.00$ \\
\hline Standard & $477 \pm 0.565$ & $217 \pm 0.03$ & $241 \pm 0.01$ & $186 \pm 0.02$ & $183 \pm 0.18$ \\
\hline Test I & $359 \pm 0.205$ & $255 \pm 0.02$ & $176 \pm 0.05$ & $176 \pm 0.05$ & $186 \pm 0.82$ \\
\hline Test II & $464 \pm 0.16$ & $245 \pm 0.01$ & $182 \pm 0.02$ & $114 \pm 0.06$ & $106 \pm 1.00$ \\
\hline
\end{tabular}

Data are averages of two determinations,

Table 4:- Total Cholesterol Result for All Groups.

\begin{tabular}{|c|c|c|}
\hline GROUPS & TOTAL CHOLESTEROL mg/dL) & Benchmark (mg/dL) $)^{\mathrm{a}}$ \\
\hline NORMAL & $110 \pm 0.006$ & Desirable $<200$ \\
\hline CONTROL & $125 \pm 0.04$ & Borderline 200-239 \\
\hline STANDARD & $106 \pm 0.02$ & Undesirable > 240 \\
\hline TEST I & $105 \pm 0.2$ & \\
\hline TEST II & $102 \pm 0.04$ & \\
\hline
\end{tabular}

Data are averages of two determinations, $a=$ Ref 36

Table 5:- High Density Lipoprotein Result for All Groups.

\begin{tabular}{|l|l|l|}
\hline GROUPS & HDL $(\mathrm{mg} / \mathrm{dL})$ & ${\text { Benchmark }(\mathrm{mg} / \mathrm{dL})^{\mathrm{a}}}^{\mathrm{a}}$ \\
\hline NORMAL & $63 \pm 0.03$ & Desirable $>60$ \\
\hline CONTROL & $64 \pm 0.05$ & Undesirable $\leq 40$ (men) $; \leq \leq 50$ (women) \\
\hline STANDARD & $74 \pm 0.10$ & \\
\hline TEST I & $69 \pm 0.04$ & \\
\hline TEST II & $71 \pm 0.18$ & \\
\hline
\end{tabular}

Data are averages of two determinations, $a=\operatorname{Ref} 36$

Table 6:- Triglyceride Result for All Groups.

\begin{tabular}{|l|l|l|}
\hline GROUPS & TRIGLYCERIDE $(\mathrm{mg} / \mathrm{dL})$ & ${\text { Benchmark }(\mathrm{mg} / \mathrm{dL})^{\mathrm{a}}}$ \\
\hline NORMAL & $138 \pm 0.05$ & Desirable $<150$ \\
\hline CONTROL & $161 \pm 0.13$ & Borderline 150-199 \\
\hline STANDARD & $130 \pm 0.04$ & Undesirable $>200$ \\
\hline TEST I & $129 \pm 0.12$ & \\
\hline TEST II & $127 \pm 0.23$ & \\
\hline
\end{tabular}

Data are averages of two determinations, $a=\operatorname{Ref} 36$ 


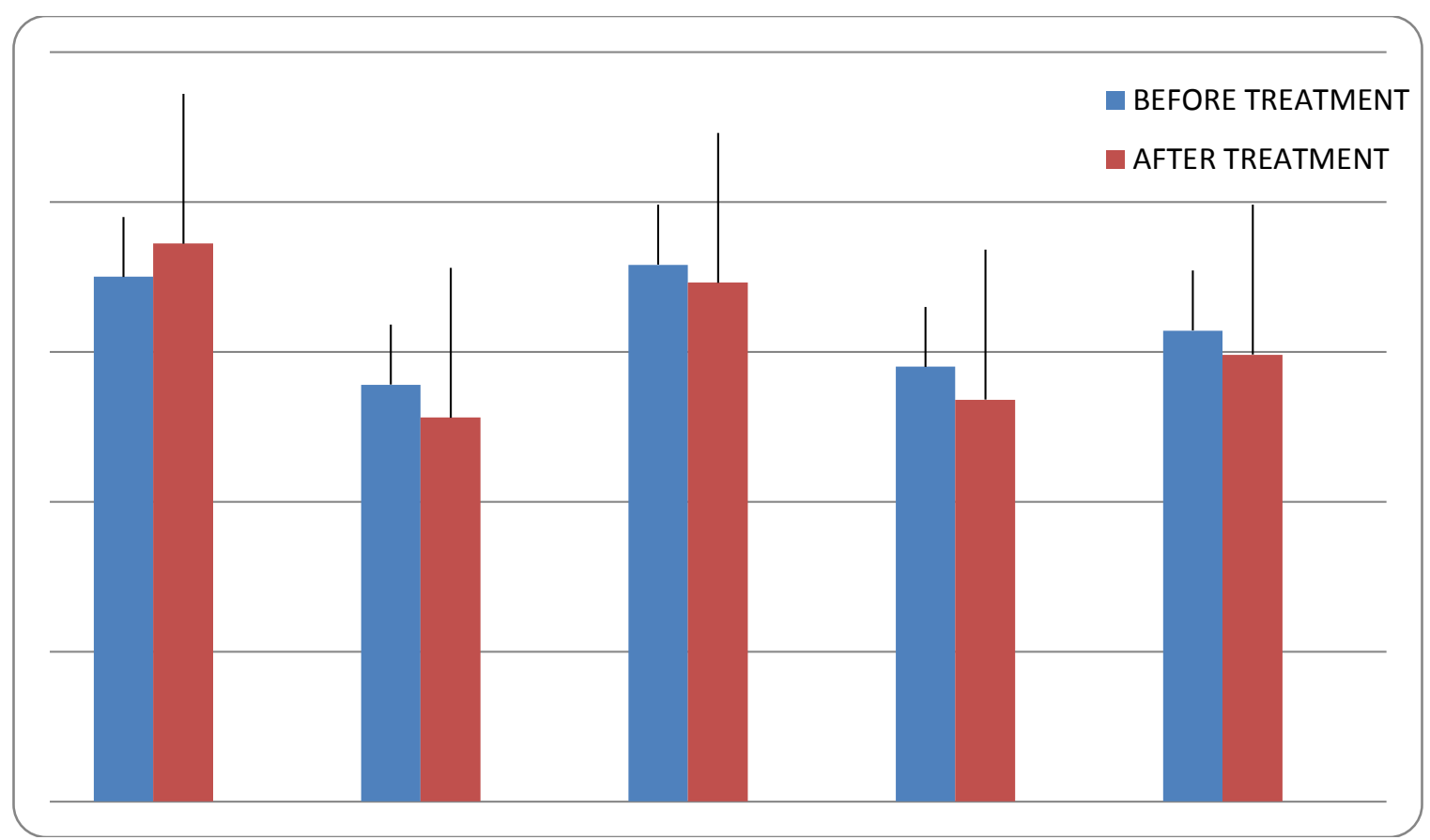

Fig. 1:-Comparison Between Body Weights Before Treatment And After A Week Treatment.

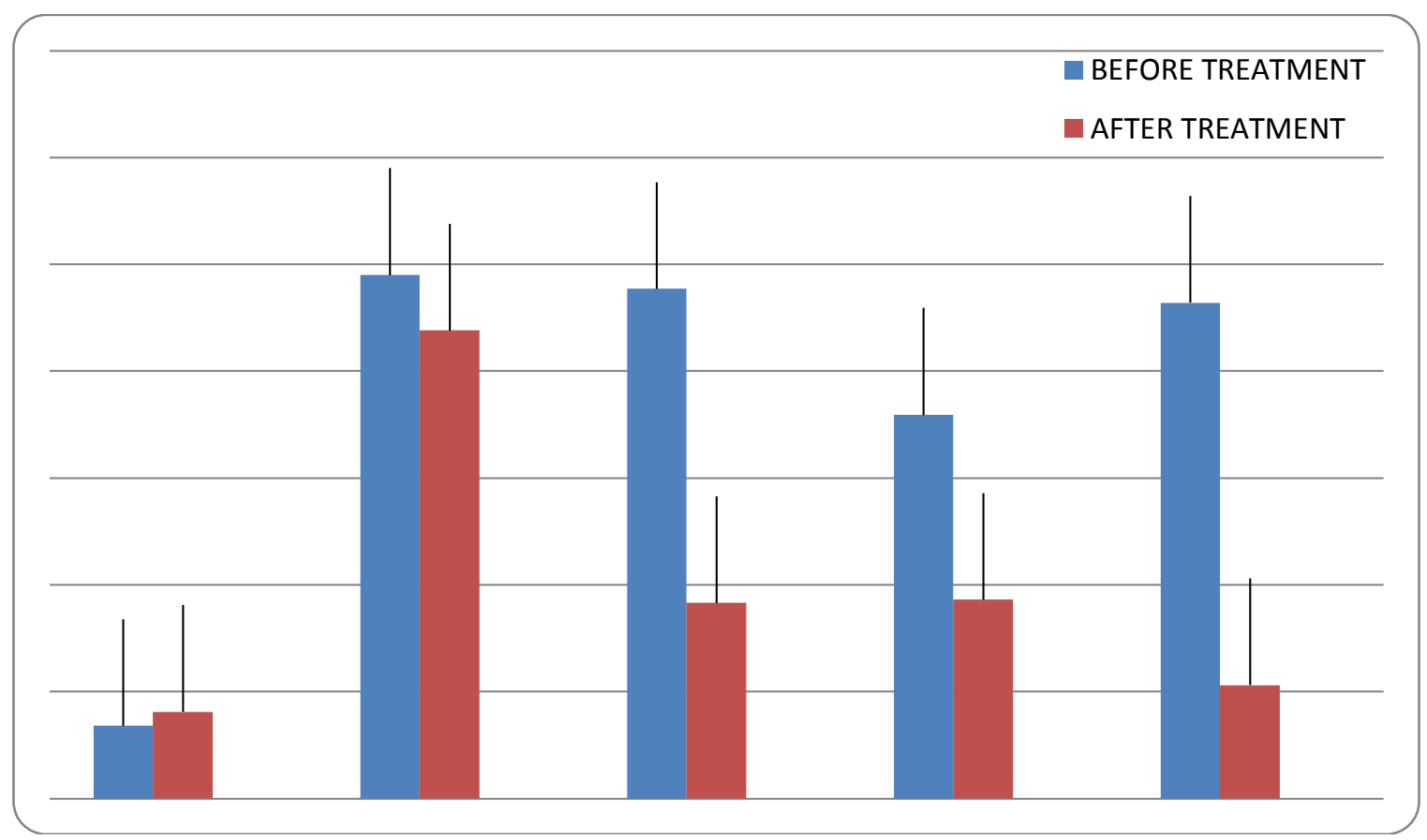

Fig. 2:- Comparison between Blood Glucose Level Before Treatment And After A Week Treatment.

\section{References:-}

1. Alamgir Z. Chowdhury, M. Ibrahim Hossain, Md. Sabir Hossain, Sohel Ahmed, Tanzila Afrin and Nurul Karim (2012): Antidiabetic Effects of Momordica Charantia (Karela) in Male long Evans Rat: Journal of Advanced Laboratory Research in Biology, 3(3): 0976-7614.

2. American Diabetes Association (1998): Economic consequences of diabetes mellitus in the U.S. in 1997. Diabetes Care; 21(2): 296-309.

3. Ar'Rajab A and Ahrén B (1993): Long-term diabetogenic effect of streptozotocin in rats. Pancreas 8(1): 50-57. 
4. Chrubasik, S., Pittler, M. H. and Roufogalis, B. D. (2005): Zingiberis rhizoma: a comprehensive review on the ginger effect and efficacy profiles. Phytomedicine, 12(9): 684-701

5. Chuku L. C., Chinaka N. C. (2014): Protein and Mineral Element Levels of Some Fruit Juices (Citrus spp.) in Some Niger Delta Areas of Nigeria. International Journal of Nutrition and Food Sciences. Special Issue: Optimizing Quality and Food Process Assessment. 3(6-1): 58-60.

6. Connell D., Sutherland M. (1969): A re-examination of gingerol, shogaol and zingerone, the pungent principles of ginger (Zingiber officinale Roscoe). Australian Journal of Chemistry; 22: 1033-43.

7. Dorr, R. T. and Fritz, W. L. (1980): Cancer chemotherapy. Hand book. London, Kinapton, pp.632-37.

8. Duke, J. A. and Ayensu, E. S. (1985): Medicinal Plants of China. Medicinal Plants of the World. Vol. 1. Algonac, MI: Reference Publications, Inc, 362.

9. Ebong, P. E., Atangwho, I. J., Eyong, E. U. and Egbung, G. E. (2008): The anti-diabetic efficacy of combined extracts from two continental plants: Azadirachta indica (Neem) and Vernonia amygdalina (bitter leaf). American Journal of Biochemical and Biotechnology, 4(3): 239 - 244.

10. Fadillioglu, E., Kurcer, Z., Parlakpinar, H., Iraz, M. and Gursul, C. (2008): Melatonin treatment against remote open injury induced by renal ischemia reperfusion injury in diabetes mellitus. Archiological Pharmacological Response, 31(6): 705-12.

11. Fenwick G. R. And Hanley A. B. (1985): The genus Allium. Part 2. Critical Review. Food Science Nutrition, 22: 273-377.

12. Firas, S. A. (2013): Synergistic effect of cinnamon, green tea and ginger on enhancing postprandial blood glucose. Parkinstan Journal of Biological Sciences 16(2): 74-79.

13. Gu, D., Arnush, M. and Sarvetnick, N. (1997): Endocrine/exocrine intermediate cells in Streptozotocin treated Ins-IFN gamma transgenic mice. Pancreas, 15(3):246-50.

14. Kandangath R. A., Garlapati P. K., Nallamuthu, I. (2015): Nutritional, Pharmacological and Medicinal Properties of Momordica Charantia. International Journal of Nutrition and Food Sciences, 4(1): 75-83.

15. Khadem A. M. H., Karimipour, M., Salami, S. and Shirpoor, A. (2008): The Effect of ginger (Zingiber officinale) on Oxidative Stress Status in the Small Intestine of Diabetic Rats; International Journal Endocrinology and Metabolism, 6(3): 144-150.

16. Leslie Taylor (2002): Herbal Secrets of the Rainforest, 2nd edition, Sage Press, Inc., Austin.

17. Josling, P.A. (2005): The heart of garlic Nature's aid to healing the human by chronic inhibition of nitric oxide synthesis. Life Sciences, 62:71-77.

18. Londhe, V. P., Gavasane A. T., Nipate S. S., Bandawane D. D., Chaudhari P. D. (2011): Role of garlic (allium sativum) in various diseases: an overview. Journal of Pharmaceutical Research and Opinion, 1(4): 129 - 134.

19. National Diabetes Fact Sheet. 2011.

20. National Institute of Health (2010): Guide for the care and use of laboratory animals, $8^{\text {th }}$ edn. National Research Council of the National Academies, The National Academies Press, Washington DC.

21. Newall, C. A., Anderson, L. A., Phillipson, J. D. (1996): Herbal medicines: a guide for health-care professionals. London: Pharmaceutical Press ix, 296.

22. Nwanjo, H. U., and Nwokoro, E. A. (2004): Anti-diabetic and biochemical effects of aqueous extract of $V$. amygdalina leaf in normoglycaemic and diabetic rats. Journal of Innovative Life Science, 7:6 -10.

23. Papaspyros N. S. The History of Diabetes (1964): In: Verlag, G. T., editors. The History of Diabetes Mellitus. Stuttgart: Thieme; p.4.

24. Petlevski, R., Hadzija, M., Bajalo, J. L. and Juretic, D. (2006): Effects of acarbose on alanine aminotransferase and aspartate aminotransferase activities in the liver of control and diabetic CBA mice. Acta Pharmacology, 56(1):87-93.

25. Piyachaturawat, P., Poprasit, J. and Glinsukon, T. (1991): Gastric mucosal secretions and lesions by different doses of Streptozotocin in rats. Toxicology Letter, 55:21-29.

26. Rakieten, N., Rakieten, M. L. And Nadkarm, M. V. (1963): Studies on the diabetogenic actions of streptozotocin. Cancer Chemotherapy Reports, 29, 91-98.

27. Raman, A. and Lau, C., (1996): Anti-diabetic properties and phytochemistry of Momordica charantia L. (Cucurbitaceae). Phytomedicine, 2: 349-362.

28. Shailah, A. (2010): Ginger extract (Zingiber officinale) triggers apoptosis and g0/g1 cells arrest in HCT 116 and HT 29 colon cancer cell lines. African Journal of Biomedical Research, 4(4): 134-142

29. Singh, V. K, and Singh D. K. (2008): Pharmacological Effects of garlic (Allium sativum L.). Annual Review of Biomedical Sciences; 10: 6-26. 
30. Uma, B., Hemantkumar, S. C., Geetika, K. and Abul, K. N. (2014): Antidiabetic effects of Embelia ribes extract in high fat diet and low dose streptozotocin-induced type 2 diabetic rats, Frontiers in Life Science, 7®3-4), 186196.

31. Wang, W. and Wang, Z. (2005): Studies of commonly used traditional medicine-ginger, Zhongguo Zhongyao Zazhi, 30(20): 1569-1573.

32. White, D. A. and Baxter M. (1994): Diabetes mellitus. In: Hormones and Metabolic Control, 2nd edn. London: Arnold. p 79-92.

33. Wild, S., Roglic, G., Green, A. and King, H. (2004): Global prevalence of diabetes: Estimates for the year 2000 and projections for 2030. Diabetes Care, 27: 1047-53.

34. Zafar, M., Naeem-ul-Hassan, N. S., Ahmed, M. and Kaim, K. Z. A. (2009): Altered liver morphology and enzymes in streptozotocin-induced diabetic rats. International Journal of Morphology, 27(3):719-25, a.

35. Zafar, M.; Naeem-ul-Hassan Naqvi, S.; Ahmed, M. and Kaim, K. Z. A. (2009): Altered kidney morphology and enzymes in streptozotocin-induced diabetic rats. International Journal of Morphology., 27(3):783-90, b

36. Cholesterol levels. www.welladvantage.com/employees. 